\section{Synthesis and characterization of graphene layers from rice husks}

1,2Seitzhanova M.A.*, ${ }^{2}$ Chenchik D.I.,

2,3yeleuov M.A., ${ }^{1,2}$ Mansurov Z.A. ${ }^{4}$ Capua R.D., ${ }^{1}$ Elibaeva N.S.

${ }^{1}$ Al-Farabi Kazakh National University, Almaty, Kazakhstan

${ }^{2}$ Institute of Combustion Problems, Almaty, Kazakhstan

${ }^{3}$ Satpayev University, Almaty, Kazakhstan ${ }^{4}$ University of Naples Federico II, Naples, Italy *E-mail: makpal_90.90@mail.ru
In this work, a method of obtaining graphene layers from natural source specifically from rice husk was developed. A rice husk $(\mathrm{RH})$ was used as a raw material, and potassium hydroxide was used as activation agent. The graphene layers were obtained after four successive stages: pre-carbonization, desilication in $1 \mathrm{M} \mathrm{NaOH}$ solution, chemical activation and exfoliation of the carbonized rice husk. The obtained samples were studied using Raman spectroscopy, TEM and SEM; the Raman peaks evidenced the presence of graphene multilayers in the sample. A detailed observation of Raman spectroscopy showed that the obtained samples with ratio of $1 / 4$ and $1 / 5$ $(\mathrm{RH} / \mathrm{KOH})$ consisted of graphene layers with a high content of amorphous component. The yield of the product was $\sim 3 \%$ by weight. This study can provide a new way to the large-scale synthesis of low-cost single and multi-layered graphene using rice husk or other renewable resources.

Keywords: graphene; rice husk; carbonization; exfoliation; chemical activation.

\section{Синтез слоев графена из рисовой шелухи и их характеристики}

\author{
1,2Сейтжанова М.А.*, ${ }^{2}$ Ченчик Д.И., \\ ${ }^{2,3}$ Елеуов М.А., ${ }^{1,2}$ Мансуров 3.A. \\ ${ }^{4}$ Капуа Р.Д., ${ }^{1}$ Елибаева Н.С.
}

${ }^{1}$ Казахский национальный университет имени аль-Фараби, Алматы, Казахстан

${ }^{2}$ Институт проблем горения, Алматы, Казахстан ${ }^{3}$ Сатпаевский университет, Алматы, Казахстан

4Университет Неаполя Федерико II, Неаполь, Италия

*E-mail: makpal_90.90@mail.ru
В данной работе разработан метод получения слоев графена из природного ресурса. В качестве исходного материала использована рисовая шелуха (РШ), а в качестве активирующего реагента использован гидроксид калия. Слои графена были получень последовательными стадиями: предварительная карбонизация, десиликация в $1 \mathrm{M}$ растворе $\mathrm{NaOH}$, химическая активация и эксфолиация карбонизированной рисовой шелухи. Полученные образцы исследованы с использованием Рамановской спектроскопии, просвечивающей и сканирующей электронной микроскопии. Рамановские пики подтвердили наличие графеновых многослойных слоев в образце. Подробное наблюдение с использованием Рамановской спектроскопии показало, что полученные образцы соотношением $1 / 4$ $1 / 5$ (РШ/КОН) состоят из графеновых слоев с высоким содержанием аморфного компонента. Выход продукта составлял 3 мас.\%. Это исследование может обеспечить новый способ крупномасштабного синтеза однослойного и многослойного графена с использованием рисовой шелухи или других возобновляемых ресурсов.

Ключевые слова: графен; рисовая шелуха; карбонизация; эксфоляция; химическая активация.

\section{Күріш қауызынан графен қабаттарын синтездеу және олардын сипаттамалары}

\footnotetext{
1,2Сейтжанова М.А.*, 2Ченчик Д.И. 2,3Елеуов М.А., ${ }^{1,2}$ Мансуров 3.A. ${ }^{4}$ Капуа Р.Д., ${ }^{1}$ Елибаева Н.С.

1Әл-Фараби атындағы Қазақ ұлттық университеті, Алматы, Қазақстан Жану проблемалары институты, Алматы, Қазақстан ${ }^{3}$ Сәтбаев атындағы университет, Алматы, Қазақстан

${ }^{4}$ Неаполь Федерико II Университеті, Неаполь, Италия *E-mail: makpal_90.90@mail.ru
}

Бұл жұмыста табиғи ресурстан графен қабаттарын алу әдісі жасалған. Бастапқы материал ретінде күріш қауызы, ал активтендіруші реагент ретінде калий гидроксиді қолданылған. Графен қабаттары сатылы стадиямен алынған: алдын-ала карбонизациялау, карбонизделген күріш қауызын $1 \mathrm{M} \mathrm{NaOH}$ ерітіндісінде десиликациялау, химиялық активациялау және эксфоляциялау. Алынған үлгілер Раман спектроскопия, трансмиссия және сканирлеуші электрондық микроскопия қолданып зерттелінді. Раман спектрлері үлгінің құрамында көп қабатты графеннің бар екенін растады. Раман спектроскопиямен терең зерттеу нәтижесінде $1 / 4$ және $1 / 5(\mathrm{KK} / \mathrm{KOH})$ қатынасында алынған үлгілер графен қабаттарынан және аморфть көмірден тұратыны анықталды. Өнімнің жалпы шығымы 3 мас.\%. Бұл зерттеу жұмысы күріш қауызынан немесе басқа да жаңартылымды ресурстардан бір қабатты және көп қабатты графенді ауқымды синтездеудің жаңа әдісін қамтуы мүмкін.

Түйін сөздер: графен; күріш қауызы; карбонизация; эксфоляция; химиялық активация. 


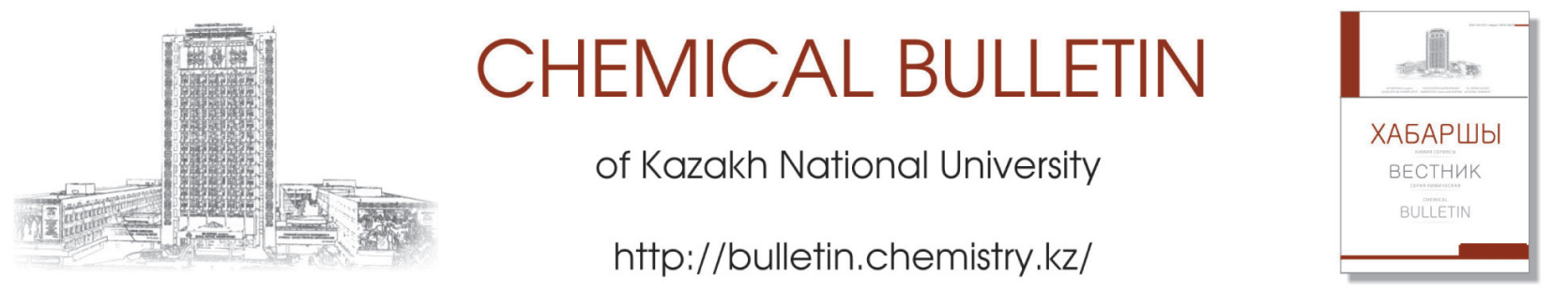

http://doi.org/10.15328/cb986

\title{
Synthesis and characterization of graphene layers from rice husks
}

\author{
1,2Seitzhanova M.A. ${ }^{*},{ }^{2}$ Chenchik D.I., ${ }^{2,3}$ Yeleuov M.A., ${ }^{1,2}$ Mansurov Z.A., \\ ${ }^{4}$ Capua R.D., ${ }^{1}$ Elibaeva N.S.
}

\author{
${ }^{1}$ Al-Farabi Kazakh National University, Almaty, Kazakhstan \\ ${ }^{2}$ Institute of Combustion Problems, Almaty, Kazakhstan \\ ${ }^{3}$ Satpayev University, Almaty, Kazakhstan \\ ${ }^{4}$ University of Naples Federico II, Naples, Italy \\ *E-mail:makpal_90.90@mail.ru
}

\section{Introduction}

Graphene is a single layer two-dimensional carbon structure, the surface of which is laid out in regular hexagons with sides of $0.142 \mathrm{~nm}$ and carbon atoms at the vertices. Graphene is a semimetal with a small overlap of the conduction and valence bands. Currently, much attention is paid to graphene because of its unusual and potentially useful properties such as high electrical and thermal conductivity, the dependence of electronic properties on the presence of attached radicals of different nature on the surface of graphene, an adjustable band gap, quantum Hall effect, extremely high mobility of charge carriers, high elasticity and good electromechanical characteristics. These properties allow using it in future as the basis for new nanomaterials with improved mechanical, electrical and thermal physical characteristics, as well as an element of nanoelectronic devices [1]. The researches on electronic properties of thin films by Geim and Novoselov have enabled the development of a new stage in the life of graphene [2]. They showed the unique electronic properties of graphene, which gave a new impetus for researchers to further their studies. If in 2007 were published 797 articles devoted to graphenes, in 2008 there were 801 publications, in 2016 their number has already exceeded 1000 titles [3-5].

For several years, since the discovery of the first method for the obtaining of graphene based on the mechanical splitting of graphite layers, the efforts of many research laboratories have been aimed at developing new, more effective approaches to solving this problem. Many methods, such as liquid-phase separation of graphite, its oxidation, graphene synthesis by chemical vapor deposition, epitaxial growth of graphene on a metal surface, thermal decomposition of carbide, obtaining of graphene in an electric arc, have been used to obtain graphene $[3,4]$. However, these methods are very timeconsuming and have a low yield of graphene. Therefore, the search for new, simpler and cost-effective methods for the synthesis of graphene is an actual task. A promising method can be to obtain graphene layers from agricultural wastes. Agricultural wastes, e.g., rice husks, poplar tree, saxaul, corncob and apricot stones are usually decomposed by burning, which produces ash residues used as sorbents. Among these materials, rice husks have high sorption potential [5] and their stocks are huge in the Republic of Kazakhstan and other countries. Therefore, the obtaining of graphene from rice husks opens the possibility of developing various applications due to its inexpensive, simple and scalable production.

\section{Experiment}

In this work, rice husk (RH), which is a multi-tonnage and renewable waste was used as a raw material. $\mathrm{KOH}$ was used as a typical chemical reagent to induce porosity. This method of obtaining graphene oxide from rice husk was different from the one reported in [6-8]. The carbonized rice husk containing graphene was obtained in four successive stages: precarbonization, desilication, activation and exfoliation of the carbonized rice husk (CRH) (Figure 1).

2.1 Pre-carbonization of $\mathrm{RH}$

Firstly, the RH was washed several times with distilled water to remove impurities, and then dried at $110^{\circ} \mathrm{C}$ for $1 \mathrm{~h}$. 


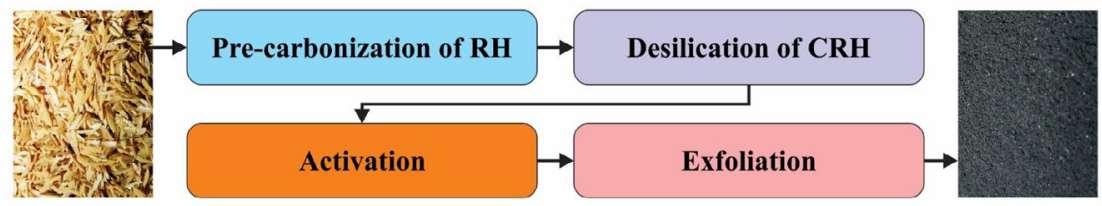

Figure 1 - Illustration of the process of obtaining graphene layers

The pre-carbonization of $\mathrm{RH}$ was carried out in a rotating reactor in an inert medium at $250-300^{\circ} \mathrm{C}$, with an argon delivery rate of $\sim 5 \mathrm{~cm}^{3} / \mathrm{min}$, the carbonization time was $45 \mathrm{~min}$ [9].

\subsection{Desilication of $\mathrm{CRH}$}

The resulting samples of $\mathrm{CRH}(60 \mathrm{~g})$ were desilicated in $3 \mathrm{~L}$ of $1 \mathrm{M} \mathrm{NaOH}$ solution and heated to $110^{\circ} \mathrm{C}$ for $3 \mathrm{~h}$ to remove $\mathrm{SiO}_{2}$, then they were let to settle. The solution was decanted to remove sodium silicate. After that the solution was washed 5-7 times with distilled water (through boiling- sedimentationdecantation) to reach the equilibrium of $\mathrm{pH}^{\sim} 7$ and dried in hot air oven for at least $2 \mathrm{~h}$ at $110^{\circ} \mathrm{C}[10]$.

\subsection{Activation}

A series of 5 samples of the dried $\mathrm{CRH}$ was mixed with crushed $\mathrm{KOH}$ at different temperatures and ratios (Table 1 ). The mixtures were compacted in an iron crucible, and the crucible

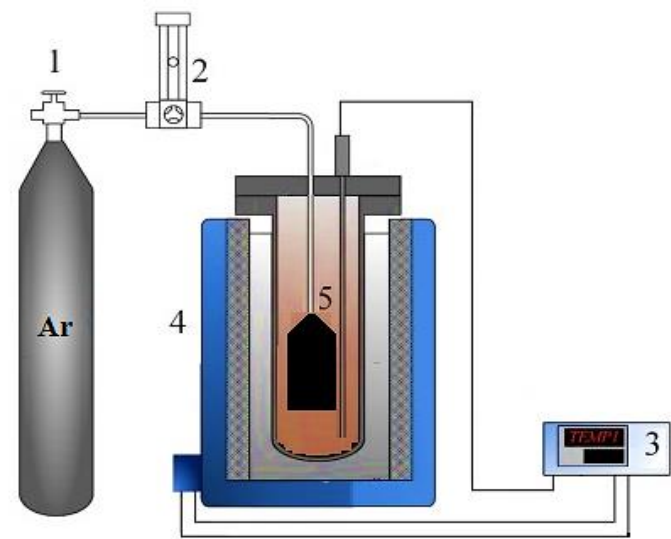

1 - Argon cylinder, 2 - mass flowmeter, 3 - temperature controller, 4 - carbonization reactor, 5 - iron crucible.

Figure $\mathbf{2}$ - Schematic diagram of self-built carbonization setup was annealed at $850^{\circ} \mathrm{C}$ for $2 \mathrm{~h}$. To avoid oxidation, argon was supplied at a rate of $5 \mathrm{sccm}$ (standard cubic centimeter per minute). After activation treatment, the resulting samples were washed with distilled water several times to reach the equilibrium of $\mathrm{pH} \sim 7$, and the filtered samples were dried at $100^{\circ} \mathrm{C}$ for $24 \mathrm{~h}$. The schematic diagram of self-built carbonization setup is shown in Figure 2.

\subsection{Exfoliation}

The exfoliation process of the $\mathrm{CRH}$ was carried out in a solution of hydrogen peroxide $\left(\mathrm{H}_{2} \mathrm{O}_{2}, 37 \%\right)$ for $48 \mathrm{~h}$, to remove amorphous carbon from the samples. After exfoliation process, the resulting samples were washed and dried with the procedure described above. The yield of the product was $~ 3 \%$ by weight.

\section{Results and Discussion}

Ko and Day [11] reported the effect of pre-carbonization during the two-stage continuous carbonization process on the final properties of carbon nanomaterials. The progression of pre-carbonization and carbonization were monitored through measurements of density, elemental composition, mechanical properties, and the stacking height of the carbon layer plane. Therefore, we pre-carbonized our $\mathrm{RH}$ before carbonization in an inert atmosphere. The surface area of the resulting samples were investigated on the analyzer "Sorbtometr $M$ " by lowtemperature nitrogen adsorption method (BET-method). The standard calculations of $\mathrm{CRH}$ shows that surface area of samples lies from 270 to $350 \mathrm{~m}^{2} / \mathrm{g}$.

In the case of silicon, containing carbon composites the use of alkaline agents such as $\mathrm{NaOH}$ or $\mathrm{KOH}$ is an extra way to obtain mesoporous materials due to washing out from the matrix the water-soluble $\mathrm{Na}$ or $\mathrm{K}$ silicates formed by the reaction:

Table 1 - The investigation of optimal ratio and temperature for obtaining graphene layers

\begin{tabular}{cccccc}
\hline $\begin{array}{c}\text { Number of } \\
\text { sample }\end{array}$ & $\begin{array}{c}\text { Ratio of } \mathrm{CRH} / \mathrm{KOH}, \\
\mathrm{g} / \mathrm{g}\end{array}$ & $\begin{array}{c}\text { Temperature, } \\
{ }^{\circ} \mathrm{C}\end{array}$ & $I_{G} / I_{2 D}$ & $I_{D} / I_{G}$ & $\begin{array}{c}\text { Number of } \\
\text { layers }\end{array}$ \\
\hline 1 & $1 / 4$ & 650 & - & - \\
2 & $1 / 4$ & 750 & - & - \\
3 & $1 / 1.5$ & 850 & - & - & \\
4 & $1 / 4$ & 850 & 2.06 & 0.29 & $7-8$ \\
5 & $1 / 5$ & 850 & 1.57 & 0.39 & $4-5$ \\
\hline
\end{tabular}




$$
2 \mathrm{MeOH}+\mathrm{SiO}_{2} \rightarrow \mathrm{Me}_{2} \mathrm{SiO}_{3}+\mathrm{H}_{2} \mathrm{O}
$$

where $(\mathrm{Me}=\mathrm{Na}, \mathrm{K})$, and $\mathrm{SiO}_{2}$ serves as a template for pore formation. So we used $1 \mathrm{M} \mathrm{NaOH}$ solution to obtain porous materials [12].

Potassium hydroxide is a known hydroscopic material letting the carbonization reactions to occur at substantially lower temperatures (its melting point is $380^{\circ} \mathrm{C}$ ) compared to standard pyrolysis which, is governed mostly by radical processes leading in turn to disproportionation reactions yielding tar formation. The purpose of potassium hydroxide is therefore to provide both carbon retention (higher yields, e.g., less amount of volatiles are formed as hydrocarbon tar) and high surface area.

Although the $\mathrm{KOH}$ activation is a well-known method to generate the pore network in carbons, the activation mechanism has not been well understood because of the complexity due to the large number of variables in both the experimental parameters and the reactivity of different precursors used. In a general view, the interaction of carbon and $\mathrm{KOH}$ starts with solid-solid reactions and then proceeds via solid-liquid reactions including the reduction of potassium (K) compound to form metallic $\mathrm{K}$, the oxidation of carbon to carbon oxide and carbonate, and other reactions among various active intermediates [13].

The real reaction processes and activation mechanisms are variable depending not only on the activation parameters (i.e. amount of $\mathrm{KOH}$, activation temperature, etc.), but also on the reactivity of various carbon sources.

To determine the optimal temperature of the $\mathrm{KOH} / \mathrm{CRH}$ mixture for obtaining graphene, we took three samples and heated them at $650^{\circ} \mathrm{C}, 750^{\circ} \mathrm{C}$ and $850^{\circ} \mathrm{C}$ (Table 1 ).

We carbonized the rice husks with the addition of $\mathrm{KOH}$ in a ratio of $1 / 1.5$ (sample No. 3), 1/4 (sample No. 4) and 1/5 (sample No. 5) at $850^{\circ} \mathrm{C}$. Samples obtained at temperatures of $650^{\circ} \mathrm{C}$ (sample No. 1) and $750^{\circ} \mathrm{C}$ (sample No. 2) largely retained the amorphous phase of carbon (Figure 3). A sample obtained at $850^{\circ} \mathrm{C}$ showed the presence of a graphite phase. Calculation data for graphene layers based on Raman spectroscopy indicate a decrease in the number of layers with an increase in the $\mathrm{RH} / \mathrm{KOH}$ ratio from $1 / 4$ to $1 / 5$.

A quick and accurate way to determine the number of layers of graphene is of a great importance in accelerating the study of this material. As in the previous works [14-15], we determined the number of graphene layers obtained by employing the proposed method.

It is well known, that the typical Raman spectrum of graphene exhibits three peaks: peak $D$ at $1351 \mathrm{~cm}^{-1}$, peak $G$ at $1580 \mathrm{~cm}^{-1}$, and peak $2 D$ at $2700 \mathrm{~cm}^{-1}$. The ratio between the intensities of peak $G\left(I_{G}\right)$ and peak $2 D\left(I_{2 D}\right), I_{G} / I_{2 D}$ gives an estimate of the number of layers [16]. For monolayer graphene, this ratio is less than unity. The ratio between the intensities of peak $D\left(I_{D}\right)$ and peak $G\left(I_{G}\right), I_{D} / I_{G}$ evaluates the defectiveness of graphene layers. Figure 4 shows Raman spectra of graphene layers obtained from CRH (samples No.4 and No.5). The maximum number of graphene layers is less than ten (Table 1) as indicated by the ratio between the peaks' intensities $I_{G} / I_{2 D}$. It was shown [17] that the ratio of $I_{G} / I_{2 D}=1.3$ corresponds to three layers of graphene, whereas the authors of [18] found that $I_{G} / I_{2 D}=1.8-2.4$ corresponds to 5-10 layers of graphene.

According to Raman spectra, high-quality graphene multilayer was not found in samples 1, 2, and 3 (Figure 3 ), in contrast to samples 4 and 5 . These results indicate that in our method, a $\mathrm{CRH} / \mathrm{KOH}$ ratio of $1 / 4$ and $1 / 5$ at $850^{\circ} \mathrm{C}$ should be used during the preparation.

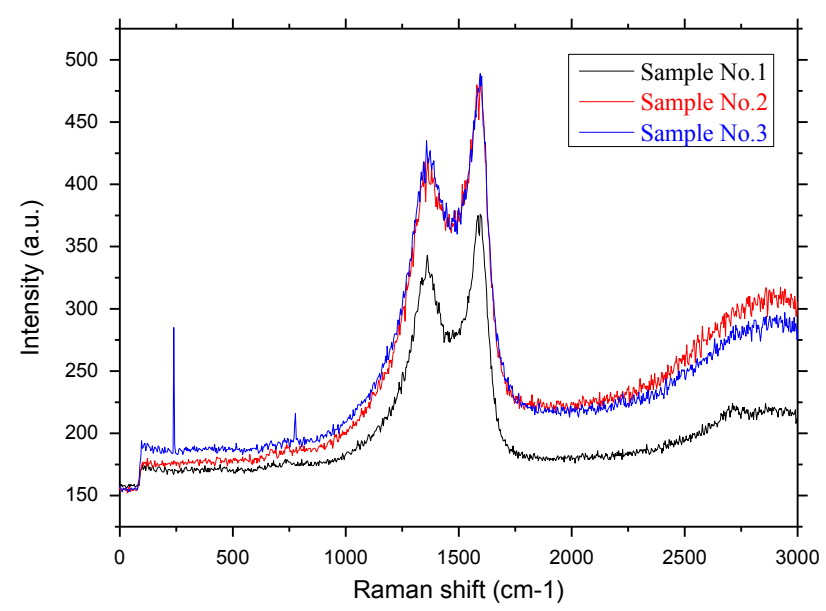

Figure 3 - Raman spectra of samples No. 1, 2 and 3

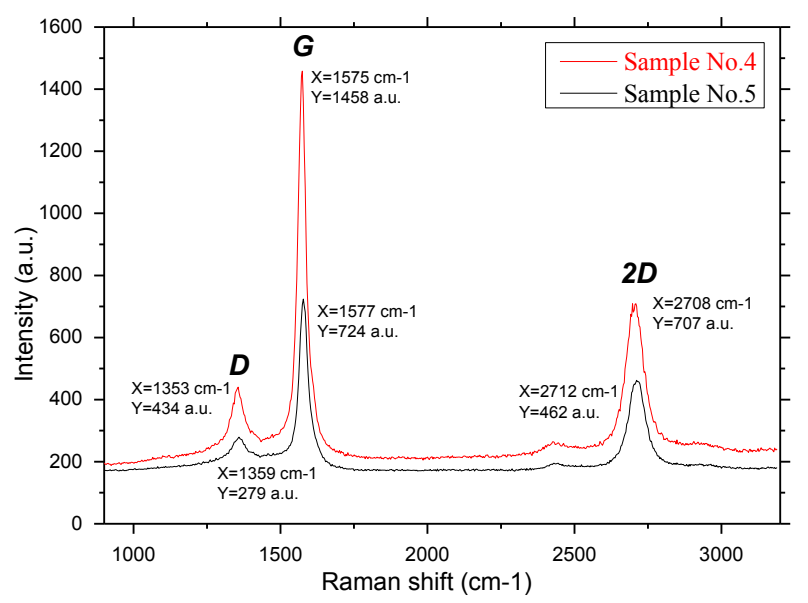

Figure 4-Raman spectra of sample No.4 and No.5

To identify surface morphological features of sinthesized samples, we have used scanning electron microscopy (SEM). Studies were conducted on the microscope Quanta 3D 200i Dual System, FEl. Samples have a complex structure, however, they exhibit a characteristic macrostructure and texture of the surface. Figure 5 shows SEM-images of the samples of sinthesized samples. 

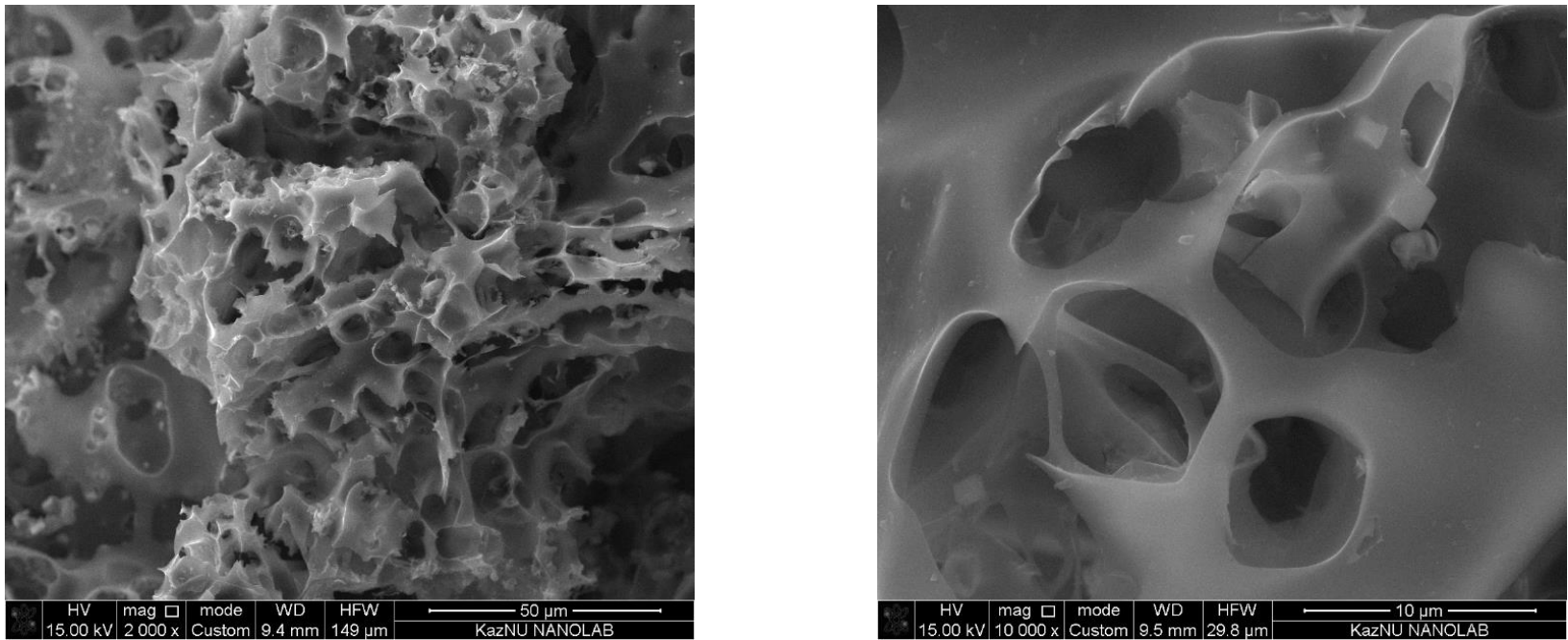

Figure 5 - SEM-images of the CRH

As shown in Figure 5, obtained samples of carbon material have a developed surface, and this method generally does not affect the macrostructure of the samples, which is determined by the original structure of the $\mathrm{RH}$. However, carbonization and chemical activation increase the specific surface of samples, as shown in previous studies [19].

Figure 6 shows the data of elemental analysis of the sample. The sample contains small amounts of silicon (compared to the feedstock). Thus, in the process of desilication, a small amount of silicon ( $4 \mathrm{wt} \%$ ) remains in the samples.

Next, the structures of graphene layers were analyzed by transmission electron microscopy (TEM) using a JEM-2100 (JEOL, Japan) instrument with high stability of high voltage and beam current along with an excellent electron-optical system. A TEM image of graphene obtained from $\mathrm{CRH}$ by activation with $\mathrm{KOH}$ is shown in Figure 7. Samples have defects and inclusions of an amorphous carbon component, but there are sections of layers without defects with a homogeneous surface structure.

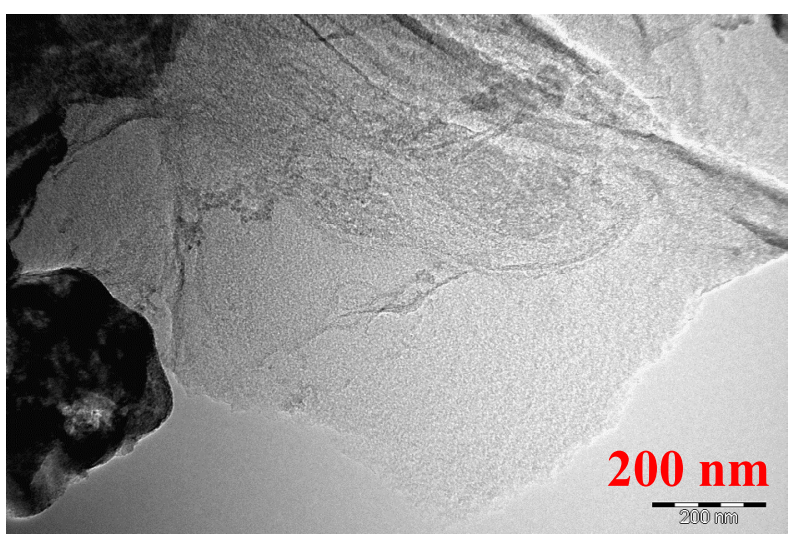

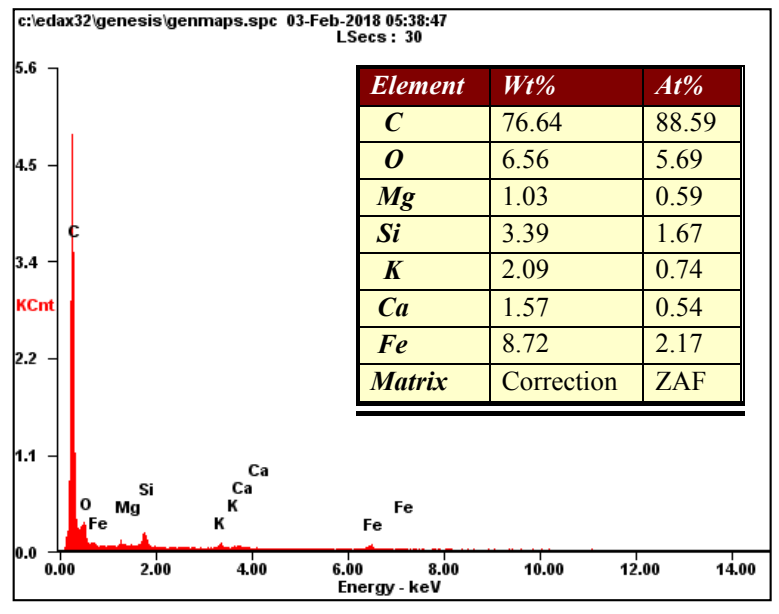

Figure 6 - Elemental composition of the sample No.5

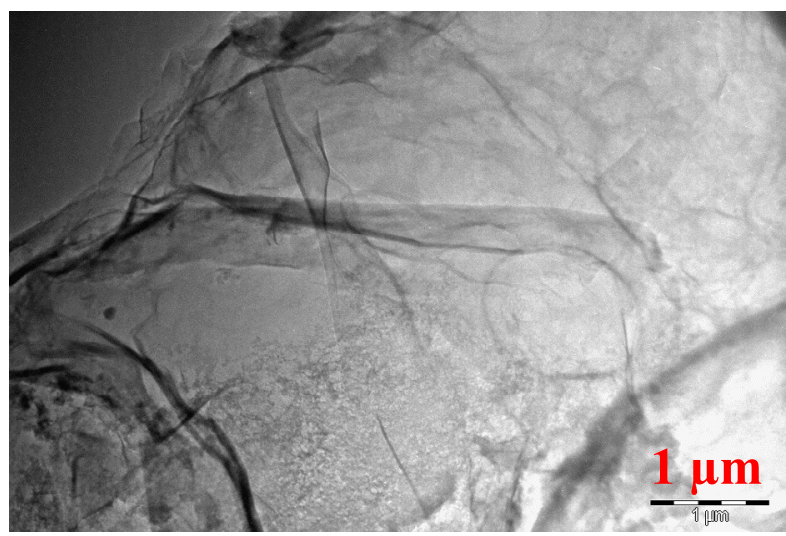

Figure 7 - TEM microimages of the graphene layers 


\section{Conclusions}

A method of obtaining graphene layers from rice husk was developed. Graphene layers were obtained from rice husk by potassium hydroxide activation followed by alkaline desilication. Rice husk samples were subjected to carbonization at the following conditions: $2 \mathrm{~h}$ of activation time, $850^{\circ} \mathrm{C}$ and ratio of rice husk $/ \mathrm{KOH}$ (wt/wt) was $1 / 5$. Concentration of $\mathrm{NaOH}$ desilication solution was $1 \mathrm{M}$. The obtained samples were studied using Raman spectroscopy, TEM and SEM; the Raman peaks put in evidence the presence of graphene multilayers in the sample. A detailed observation by Raman spectroscopy showed that the obtained samples No. 4 and 5 consisted of graphene layers with a high content of amorphous component. The yield of the product was $\sim 3 \%$ by weight. Nevertheless, this method appears promising for the production of high quality graphene layers, since the layers observed in the images of the TEM have an edge structure with domains of several nanometers in addition to topological defects and nanoscale pores. The obtained results show the possibility of obtaining graphene by a simple, cost-effective and scalable method, by carbonization the $\mathrm{CRH}$ with $\mathrm{KOH}$.

\section{Acknowledgments}

Authors would like to thank the National Tanotechnological Laboratory of Open Type of al-Farabi Kazakh National University (Almaty, Kazakhstan) for obtaining SEM images and Raman spectra, and the Laboratory of Radiation Material Science of the Institute of Nuclear Physics (Almaty, Kazakhstan) for obtaining TEM images.

\section{References (GOST)}

1 Mansurov Z.A. Soot formation: textbook. - Almaty: Kazakh University, 2015.

2 Novoselov K.S., Geim A.K., Dubonos S.V., Hill E.W., Grigorieva I.V. Subatomic movements of a domain wall in the Peierls potential // Nature. - 2003. - Vol.426. - P.812-816.

3 Berger C., Song Z., Li X., Wu X., Brown N., Naud C., Mayou D., et al Electronic confinement and coherence in patterned epitaxial graphene // Science. - 2006. - Vol.312. - P.1191-1196.

4 Dresselhaus M.S., Araujo P.T. Perspectives on the 2010 Nobel Prize in physics for graphene // ASC Nano. - 2010. Vol.4(11). P.6297-6302.

5 Korobochkin V.V., Nguyen M.H., Usol'ceva N.V., Nguyen V.T. Production of activated carbon by pyrolysis of rice husk of Vietnam // Proceedings of Tomsk Polytechnic University. Engineering Georesources. - 2017. - Vol.328(5). - P.6-15.

6 Muramatsu H., Kim Y.A., Hayashi T. Synthesis and characterization of graphene from rice husks // TANSO. - Vol.275. - P.182-190.

7 Muramatsu H., Kim Y.A., Yang K.S., Silva R.C., Toda I., Yamada T., et al. Rice husk-derived graphene with nano-sized domains and clean edges // Small. - 2014. - Vol.10(14). - P.2766-2770.

8 Singh P., Bahadur J., Pal K. One-step one chemical synthesis process of graphene from rice husk for energy storage applications // Graphene. - 2017. - Vol.6. - P.61-71.

9 Seytzhanova M.A., Kerimkulova M., Shyntoreev E., Azat S., Kerimkulova A., Mansurov Z. Development of the method for obtaining carbon ceramic adsorbents based on porous carbon // Chemical Bulletin of Kazakh National University. - 2015. - Is.2(78). - P.37-41.

10 Jandosov J.M., Shikina N.V., Bijsenbayev M.A., Shamalov M.E., Ismagilov Z.R., Mansurov Z.A. Evaluation of synthetic conditions for $\mathrm{H}_{3} \mathrm{PO}_{4}$ chemically activated rice husk and preparation of honeycomb monoliths // Eurasian Chemico-Technological Journal. - 2009. - Vol.11. - P.245-252.

11 Ko T.H., Day T.C. The effect of pre-carbonization on the properties of PAN-based carbon fibers // Polymer Composites. - 1994. - Vol.15. - P.401-407.

12 ГОСТ 25699.4-90. Углерод технический для производства резины. Метод определения удельной адсорбционной поверхности. Опубл. 05.12.1990, введен в дейст. 30.06.1991, Государственный стандарт союза ССР.

13 Wang J., Kaskel S. KOH activation of carbon-based materials for energy storage // Journal of Materials Chemistry. - 2012. Vol.22. - P.23710-23725

14 Seitzhanova M.A., Chenchik D.I., Mansurov Z.A., Capua D.R. Development of a method of obtaining graphene layers from rice husk // Functional Nanostructures Proceedings. - 2017. - 1(3). - P.6-8

15 Seitzhanova M.A., Mansurov Z.A., Chenchik D.I., Tanirbergenova S.K., Daulbaev C.B. Production of graphene based on rice husk for the demineralization of sea water using membrane technology. Proceedings of the II Conference of students and young scientists "Chemical Physics and Nanomaterials". - 2017. - Almaty, Kazakhstan. - P.48.

16 Prikhod'ko N.G., Mansurov Z.A., Auelkhankyzy M., Lesbaev B.T., Nazhipkyzy M., Smagulova G.T. Flame synthesis of graphene layers at low pressure // Russian Journal of Physical Chemistry B. - 2015. - Vol.9, Is.5. - P.743-747.

17 Reina A., Jia X., Ho J., et al. Synthesis of organic dye-impregnated silica shell-coated iron oxide nanoparticles by a new method // Nanoscale Research Letters. - 2008. - Vol.3. - P.496 
18 Robertson A.W., Warner J.H. Hexagonal single crystal domains of few-layer graphene on copper foils // Nanoscale Research Letters. - 2011. - Vol.11, Is.3. - P.1182-1189.

19 Jandosov J.M., Mikhalovsky S.V., Howell C.A., Mansurov Z.A., Chenchik D.I., Kosher B.K., et al. Synthesis, Morphostructure, surface chemistry and preclinical studies of nanoporous rice husk-derived biochars for gastrointestinal detoxification // Eurasian Chemico-Technological Journal. - 2017. - Vol.19, Is.4. - P.303-313.

\section{References}

1 Mansurov ZA (2015) Soot formation: textbook. Kazakh University, Almaty, Kazakhstan. ISBN 978-601-04-0730-5

2 Novoselov KS, Geim AK, Dubonos SV, Hill EW, Grigorieva IV (2003) Nature 426:812-816. http://doi.org/10.1038/nature02180

3 Berger C, Song Z, Li X, Wu X, Brown N, Naud C, Mayou D, et al (2006) Science 312: 1191-1196. http://doi.org/10.1126/ science. 1125925

4 Dresselhaus MS, Araujo PT (2010) ASC Nano 4(11):6297-6302. http://doi.org/10.1021/nn1029789

5 Korobochkin VV, Nguyen MH, Usol'ceva NV, Nguyen VT (2017) Proceedings of Tomsk Polytechnic University. Engineering Georesources [Izvestiya TPU. Inzhiniring georesursov] 328(5):6-15.

6 Muramatsu H, Kim YA, Hayashi T (2016) TANSO 275:182-190. http://doi.org/10.7209/tanso.2016.182

7 Muramatsu H, Kim YA, Yang KS, Silva RC, Toda I, Yamada T, et al (2014) Small 10(14):2766-2770. http://doi.org/10.1002/ smll.201400017

8 Singh P, Bahadur J, Pal K (2017) Graphene 6:61-71. http://doi.org/10.4236/graphene.2017.63005

9 Seitzhanova M.A., Kerimkulova MR, Shyntoreev EB, Azat S, Kerimkulova AR, Mansurov ZA (2015) Chem Bull Kazakh Univ 2(78):37-

41. $h$ ttp://doi.org/10.15328/cb569

10 Jandosov JM, Shikina NV, Bijsenbayev MA, Shamalov ME, Ismagilov ZR, Mansurov ZA (2009) Eurasian Chem Tech J 11:245-252

11 Ko TH, Day TC (1994) Polym Composite 15:401-407. http://doi.org/10.1002/pc.750150604

12 GOST 25699.4-90 Carbon black for rubber industry. Method for determination of specific surface area by inert gas adsorption. Publ. 05.12.1990, State Standard of the Union of SSR [Gosudarstvennyi standard Soyuza SSR]. (In Russian)

13 Wang J, Kaskel S (2012) J Mater Chem 22:23710-23725. http://doi.org/10.1039/C2JM34066F

14 Seitzhanova MA, Chenchik DI, Mansurov ZA, D Capua R (2017) Functional Nanostructures Proceedings 1(3):6-8

15 Seitzhanova MA, Mansurov ZA, Chenchik DI, Tanirbergenova SK, Daulbaev CB (2017) Production of graphene based on rice husk for the demineralization of sea water using membrane technology. Proceedings of the II Conference of students and young scientists "Chemical Physics and Nanomaterials", Almaty, Kazakhstan. P.48.

16 Prikhod'ko NG, Mansurov ZA, Auelkhankyzy M, Lesbaev BT, Nazhipkyzy M, Smagulova GT (2015) Russ J Phys Chem B 9:743-747. http://doi.org/10.1134/S1990793115050115

17 Reina A, Jia X, Ho J, et al (2008) Nanoscale Res Lett 3:496. http://doi.org/10.1007/s11671-008-9186-5

18 Robertson AW and Warner JH (2011) Nanoscale Res Lett 11:1182. http://doi.org/10.1021/n/104142k

19 Jandosov JM, Mikhalovsky SV, Howell CA, Mansurov ZA, Chenchik DI, Kosher BK, et al (2017) Eurasian Chem Tech J 19:303-313. https://doi.org/10.18321/ectj678 